\title{
History of Hamlet Translations in Turkey
}

\section{Türkiye'de Hamlet Çevirileri Tarihi}

\section{F. Zeynep BiLGE' (1)}

${ }^{1}$ Assist. Prof., Mimar Sinan Fine Arts University, Faculty of Science and Letters, Department of Western Languages and Literatures, Istanbul, Turkey

ORCID: F.Z.B. 0000-0002-6217-8280

\section{Corresponding author:}

F. Zeynep BILGE,

Mimar Sinan Fine Arts University, Faculty of Science and Letters, Department of Western Languages and Literatures, Istanbul, Turkey

E-mail: zeynep.bilge@msgsu.edu.tr

Submitted: 08.07.2020

Revision Requested: 24.07.2020

Last Revision Received: 02.09 .2020

Accepted: 29.09 .2020

Citation: Bilge, F. Z. (2020). History of Hamlet translations in Turkey. Litera, 30(2), 603-620.

https://doi.org/10.26650/LITERA2020-0099

\begin{abstract}
Starting with a brief discussion of the first Hamlet translations in accordance with the Ottoman interest in western culture and Shakespeare in the 1880s, this study intends to present an in depth historical analysis of the modern and contemporary translations of the play. Since the act of translation is an attempt to rewrite and/or adapt a given text in the target language and culture, this analysis does not only portray the way Shakespeare is perceived by the Turks but also gives evidence to the changing nature of the Turkish culture and its understanding of language, literature, and translation throughout the years. With the close reading of translations made or conducted by academicians and translators such as Halide Edib, Can Yücel and Özdemir Nutku, this study aims at displaying the differences between these translations'target audiences/readers. Since the skopos, purpose and hence, strategy of a given translation is utterly dependant on the target audience, defining the target audience of each translation is a significant starting point. Furthermore, apart from the differences in the translators's purpose and strategy, the changes the Turkish language and culture experienced since the nineteenth century play a crucial role in presenting a historical discussion of Hamlet translations in Turkey. In this respect, while examining Hamlet's inter-temporal and inter-cultural journey in Turkey, through a close reading of translations, this paper also presents various examples of shifts of expression in Popovič's terms.
\end{abstract}

Keywords: Hamlet, Shakespeare, Hamlet in Turkey, translation history, shift of expression

ÖZ

Bu çalışma Osmanlı Imparatorluğunun 1880'lü yıllarda Batı kültürü ve Shakespeare'e gösterdiği ilginin sonucu olarak yapılan Hamlet çevirilerine kısaca değindikten sonra oyunun modern ve çağdaş çevirilerini derinlemesine incelemeyi amaçlamaktadır. Çeviri ediminin bir metni erek dilde yeniden yazma ya da uyarlama çabası olması nedeniyle, bu çözümleme yalnızca Shakespeare'in Türkler tarafından nasıl algılandığını değil, aynı zamanda dil, edebiyat ve çeviri anlayışının yıllar içerisinde nasıl dönüştüğünü de gözler önüne serer. Halide Edib, Can Yücel ve Özdemir Nutku gibi akademisyen ve çevirmenlerin yaptığı ya da yönettiği çevirilerin yakın okuma yöntemiyle incelenmesiyle söz konusu çevirilerin erek okur/izleyicilerindeki farklııkların ortaya çıkartılması hedeflenmekedir. Bir çevirinin skopos, amaç ve dolayısıyla stratejisi büyük ölçüde erek okur ya da alıcıya dayandığı için bu tartışmaya başlamadan önce her bir çevirinin erek okurunu/izleyicisini tanımlamak büyük önem taşımaktadır. Ayrıca, Türkiye'deki Hamlet çevirilerinin tarihsel incelenmesi 
sürecinde çevirmenin amaç ve stratejilerinin yanısıra Türk dili ve kültürünün on dokuzuncu yüzyıldan bu yana geçirdiği değişim de büyük rol oynamaktadır. Bu bağlamda bu çalışma, çevirilerin yakın okuma yöntemiyle incelenmesi sonucunda Hamlet'in kültürler arası gerçekleştirdiği bu zaman yolculuğunu çözümlerken Popovič'in deyiş kaydırması adını verdiği değişikliklerden örnekler de sunmaktadır.

Anahtar Kelimeler: Hamlet, Shakespeare, Türkçe çeviri, çeviri tarihi, deyiş kaydırma 


\section{Introduction}

Although the socio-political interaction between the Turks and the English developed in accordance with both countries' interest in the commerce around the Mediterranean in the second half of the sixteenth century, it is not possible to talk about a substantial communication between the two cultures until the nineteenth century. It is significant that one of the first English names to appear on the Ottoman cultural stage is Shakespeare: following the Italian and English productions of Hamlet in the 1880s in these foreign troupes' mother tongues, the first Turkish translation of the play is published in 1881 . Since then, not only the inevitable changes in Turkish language and culture since 1881, but also the differences in the scope and target audience/reader have provoked new translations. This study aims at contextualising these translations in relation to their skopos. Given the discrepancy between the target language/culture and the source language/culture, what Anton Popovič refers to as the shift of expression becomes the core of such an analysis.

Apart from the two Ottoman translations of the play, which are essentially discussed through their role and reception during the Westernisation process in the 1880s, this study focuses on six different Hamlet translations into modern Turkish. The major reason why these translations are chosen lies in the fact that they are the editions, which have been considered to be representative of the period they were first published in. Apart from the Halide Edib - Vahit Turhan translation, all five are still accessible in bookstores, attentively read by the general public who are interested in the Bard's highly acclaimed work. Considering the limits of time and space of this study, numerous translations published by minor publishing houses, private translations made by/for theatre companies, abridged translations for children and students are not included.

The Turkish audience first encounters Shakespeare after the declaration of Tanzimat in 1839. Tanzimat, literally meaning 'reorganisation,' is the reformation period aiming at introducing western ideas and ideals into the Ottoman Empire on various levels including art, science and philosophy. Vahit Turhan in his essay "Shakespeare in Turkish" illustrates the period as follows:

Outwardly Tanzimat was only a domestic political event, the Sovereign granting some rights to his subjects, a kind of Magna Carta, or better still some thing very much like the Bill of Rights, but it turned out to be the 
beginning of the Turkish Renaissance, as the Empire was now openly declaring its entrance into a new mode of thinking, into a new mode of living, in fact into a new civilisation, a civilisation with which it had been at strife for centuries. (1965, pp. 51-52)

Although there had been various local forms of performing arts before Tanzimat, the first theatres in the western sense were opened during this period, when, firstly, the foreign travelling companies and secondly, native Greek and Armenian companies performed. Due to the insufficiency of records, there are assumptions regarding the first Shakespearean play published in (Ottoman) Turkish: On the one hand, İnci Enginün's research on Shakespearean translations and their influence during the Tanzimat period suggests that the first Shakespearean play that was staged in (Ottoman) Turkish is Romeo and Juliet (1871), and the first published translation is Othello (1877) (1979, p. 17). It is believed that Romeo and Juliet was quite popular in this period because the play shares certain characteristics - including the storyline and the depiction of the main characters - with Turkish folk tales focusing on a similar type of love story. On the other hand, Turhan claims that,

the very first play put up in Turkish was in fact Othello translated and produced by one of the Armenian companies in 1860. Unfortunately, the text of it, as those of quite a few after that, is extinct. Some early foreign and Turkish literary historians claimed that the first Shakespearean play printed in Turkish was Othello; but the text ascribed to a certain Hasan Bedreddin is, as I have ascertained, in truth only a rendering of the libretto of Verdi's Opera. So the first play fully translated for print is really The Merchant of Venice published in 1885 (1965, p. 53).

Starting his paper with a brief analysis of the (lack of) cultural exchange between the East and the West until the 1850s, Turhan remarks that "Othello has been the most popular play [...] despite the fact that some of the allusions to the Turks in it are not in a particularly flattering tone." (Ibid., p. 55) Saliha Paker, however, suggests that the "reason for translating the play lay in 'its representation of the bravery of the Arabs' (Enginün, 1979, p. 22); a point which is implicative not only of many factors affecting a translator's choice, but also of the 'acceptability' factor" (1991, p. 27). 


\section{Early Translations}

Although there are certain gaps concerning the history of Shakespeare translations and stage productions in the Ottoman Empire, it is apparent that the first unabridged translation of Hamlet was made by Abdullah Cevdet, who was "a doctor of medicine, a polemist, a printer, was also known as a Shakespeare idolater as he always found a way of mentioning Shakespeare in all his talks and in all his writings" (Turhan, 1965, p. 56). He translated and published Hamlet in his own publishing house in 1908 in Cairo, which was then a part of the Ottoman Empire. Being one of the pioneers of the Westernization process in the second half of the nineteenth century and a believer of the English supremacy over other western countries' ${ }^{1}$ Cevdet's choice of source texts evidently reveals his policy as a translator: "The argument that Abdullah Cevdet's translation of Hamlet, Julius Caesar and Macbeth reflected his opposition to Abdülhamid II's absolute monarchy could be justified with the fact that the themes of the translated plays were perceived by the political authorities as threatening, since they were about the murder of kings and heads of state" (Ayluçtarhan, 2007, p. 44). Similarly, Paker argues that "the choice and the dates of publication of the above-mentioned tragedies in translation suggests that they had been intended by Cevdet to play a stimulating if not revolutionary role in the intellectual re-awakening of the Ottoman political and cultural milieu" (1986, p. 92). Apart from the discussions regarding his political and intellectual motives in translating Hamlet (1908), Julius Caesar (1908), Macbeth (1909) and King Lear (1912) respectively, Cevdet has been criticised for employing a highly ornamented Ottoman language, "full to the brim with Arabic and Persian words and phrases, and [a] style too heavy for a dramatic rendering" (Turhan, 1965, p. 56).

The next Hamlet translation that still survives was made by Kamuran Şerif in 1927 - four years after the proclamation of the Republic of Turkey. Published by the Ministry of Education as part of "Examples from World Literature" series for schools, this translation is not only abridged but also employs a thoroughly simple language when compared to that of Cevdet. This is a reflection of the attempt to educate masses and common people during the birth of a new nation after the War of Independence. However, only a year after the publication of Şerif's Hamlet translation, a grand change effects literature as well as communication and daily life in Turkey. Following the official proclamation

1 As a member of the Society of Anglophiles, "he was in conflict with other members of the Union and Progress Party in power since he supported cooperation with England during the war, whereas the others wanted an alliance with Germany" (Ayluçtarhan, 2007, p. 40). 
of the Republic of Turkey in 1923, as the successor of the Ottoman Empire, the Parliament took new measures to westernise the newly established republic. One of the most visible distinctions between the western culture and that of the Ottoman Empire was the Ottoman language, which was written in the Arabic script. Although the first two attempts to replace the Arabic script with the Latin alphabet were rejected in 1923 and 1924, the law establishing the new Turkish script - employing the Latin alphabet passed in November 1928. Turhan in his paper "Shakespeare in Turkish" not only summarises the history of Shakespearean stage productions and translations in Turkey, but also briefly comments upon the emerging modern Turkish language:

Stepping into a new civilisation, into a new culture we were faced with two alternatives: a) to adopt one of the Western languages as a medium for this new culture and become, as some Asian and African nations are now, bilingual and bi-cultural, or $b$ ) to reshape the old language to suit the new requirements. (Ibid., p. 57-58)

The Republic of Turkey embraced the second option: The newly emerging Turkish language aimed at presenting a bridge between the highly ornamented Ottoman language written and spoken by the nobility and the one spoken by the general public in daily life, which can be discussed according to Das Gupta's argument in "Language Diversity and National Development": "Before the rise of the modern state, imperial linguistic need was naturally limited to the communicational network of the notables. The people in general were outside this network" (Das Gupta, 1968, p. 17). The purification of the Turkish language became one of the main concerns of the founders of the Republic. While preserving the Ottoman heritage and building up a new nation that would be close to the western civilisation, western ideas were introduced to the common people through art and literature. Although the long-established Ottoman Empire had its own artistic and literary forms, the young Republic aimed at proposing western norms and conventions as well. In that respect, the interest in literary translations can be interpreted through Even-Zohar's argument on the translated literature within the literary polysystem:

Translated literature simply fulfils the need of a younger literature to put into use its newly founded (or renovated) tongue for as many literary types as possible in order to make it serviceable as a literary language and useful for its emerging public. Since a young literature cannot immediately create texts in all types known to its producers, it benefits 
from the experience of other literatures, and translated literature becomes in this way one of its most important systems. (1990, p. 47)

\section{Halide Edib Adıvar and Vahid Turan's Hamlet}

The first unabridged publication of Hamlet in Turkish with the Latin alphabet was translated and edited by the widely acclaimed Turkish female author Halide Edib, who was the first chair of the Department of English at Istanbul University between 1940 and 1950, and her colleague from the same department, Vahid Turhan. The translation was made as a part of the seminar programme at Istanbul University, and edited by the academic staff under the supervision of Edib and Turhan. Referring to the constant changes in the Turkish language during the 1930s and 1940s, Turhan briefly discusses their skopos: "Now, the Turkish translator [...] has to make sure that the words and expressions he is using in his rendering are those still in favour, or if new, familiar enough to be intelligible to his readers and hearers" (1965, p. 58). Furthermore, since this translation was first published during a period of extreme changes in the Turkish language ${ }^{2}$, both the printed version of the text and its stage adaptation were revised, edited and purified:

It went through two editions, and the staging of it by Muhsin Ertuğrul with fifty successive performances breaking all previous record, established one which in its turn was crushed some fifteen years later by 170 successive performances again of Hamlet, and again produced by M. Ertuğrul ${ }^{3}$. (Ibid., p. 60)

The fact that there is a lengthy introduction before the actual text and that there are only a few footnotes explaining the text on a word basis suggest that the target reader/audience of the text was presumptively similar to the translators with respect to their preknowledge of Shakespeare and the culture depicted in the play. Hence this translation can be regarded as an academic activity undertaken by academics, addressing the academic world. As Paker argues, these translations "helped to initiate serious critical scholarship in English studies in Turkey" (Paker, 1986, p. 98).

2 This translation employs a significant amount of words and phrases adapted from Persian, which is indicative of the fact that the Ottoman language has not perished, when the Ottoman script was replaced with the Latin alphabet.

3 Muhsin Ertuğrul was the first Turkish actor playing Hamlet, when Abdullah Cevdet's translation was staged in 1912. 
Part I of the translation, entitled "Notes", is divided into three major sections: the first section relates Shakespeare's life in three and a half pages. The second section however, is a twenty-nine page introduction to Hamlet including the sources of the play, and analysis of anachronisms, setting, Shakespeare's language and the metaphors within the play. The last section of the "Notes" presents an analysis of all the major characters, which inevitably presents the perception of the translators. The whole play is translated in prose suggesting that the major scope of the translation process was to focus on meaning rather than style. Turhan in his essay provides a reason for this particular decision, which is employed in all Shakespeare translations undertaken and edited by the same group:

Having no verse patterns in Turkish to give that natural flow of the blank verse, the renderings of the Department have so far been in prose, except for the songs and for certain passages, like the scene of the witches in Macbeth, which are in rhymed lines. Free verse might be considered as a good solution. (1965, p. 59)

One of the puzzles apparent in this translation is the presence of English words such as "madam" and "my lord" as a part of the Turkish dialogues. Neither the notes and foreword of the translation nor Turhan's article on the translation process offers a tangible reason for such choices: when Polonius is relating his opinion on Hamlet's disturbance to Claudius and Gertrude, he addresses the Queen as "madam". It is worthy of notice that while the first "madam" (2.2.86) is translated as "Muhterem Kraliçem" [my Honourable Queen] (Shakespeare, 1941, 33), the next "madam" in this particular dialogue is left as "Madam" (Ibid., p. 34). Although, the Turkish reader in the 1940s would have been acquainted with the word "madam" (since this word was used in addressing married non-Muslim women), it is not clear why the translators decided to translate the word in one sentence and leave it as it is on other occasions. A similar use of the original English phrase is observed in the case of "my lord". Throughout the translation, Edib and Turhan let Polonius, Rosencrantz, Guildenstern and Ophelia call Hamlet "my lord" in the Turkish text and in 3.2 Hamlet calls Polonius "my lord" as well; likewise, in 3.1 and 5.1 the word "gentleman" is left as it is. On the one hand, it can be argued that the translators deliberately chose to keep these English words as they were since they would have been known to the intellectual readers of the time. On the other hand, these untranslated words emphasize the foreignness of the text and the source culture. 


\section{Orhan Burian's Hamlet}

Hamlet is next translated by Orhan Burian, a professor of English, who studied English at Cambridge University between 1933 and 1936. He is known for his essays and translations particularly focusing on the major works of English and American literature. His Hamlet translation was first published in 1946 by Milli Eğitim Basımevi 'Ministry of Education Publishing House'. This edition is the oldest Hamlet translation, which is still in print. Since the translation was commissioned by the Ministry of Education it is not unexpected to see that there are 183 footnotes accompanying the text. The nature of these footnotes is indicative of the translator and/or the publishing house's perception of the relationship between the source text and the target reader. Sharing some common characteristics with the footnotes found in different editions of the source text in its original language, Burian's footnotes not only explain certain features of the Shakespearean theatre, or refer to the textual problems related to different editions of the source text but also function as a bridge between the source text and the target reader/audience. This binding function is present on two levels: firstly, being a scholar and a university professor, Burian comments upon the text and reads in between the lines. For instance, in 1.1, Horatio first sees the late king's ghost and says, "Such was the very armour he had on /When he th'ambitious Norway combated" (1.1.63-64). The footnote (number 9) following the Turkish translation of this section states that, "even in the very beginning, we learn that the late king was a strong and warlike man"4 (Shakespeare, 1946, p. 9). The reason of these footnotes is reflected on the cover page, which states that Burian translates and edits the play for schools. Burian not only teaches the target reader the norms and conventions of the western world, but also how to read a text without disregarding those that are hidden in between the lines. From this perspective, it is most natural to observe that his longest footnote concerns Hamlet's most celebrated soliloquy, "to be or not to be." In this footnote (number 76) Burian starts his discussion by emphasizing the fact that this soliloquy is the most well-known passage of the play and hence, the most challenging section of the play for translation. He, then, presents a detailed argument on Hamlet's thoughts behind this soliloquy referring to the totality of the text, with an extra emphasis on one of the major discussion topics for Shakespeare scholars: Hamlet's inaction. This 160-word footnote is exemplary of Burian's scholarly point of view. 
The second type of footnotes functions as an introduction to the western world for the Turkish reader. Although the late Ottoman Empire and the young Republic of Turkey were not totally foreign to the Christian culture due to the number of non-Muslims living as members of their society, it is true that the general public were not necessarily accustomed to the western, Christian practices and conventions. The footnote (number 35) accompanying the scene in which the Ghost is describing how he was murdered without being allowed to say his last prayers states that, "In Christianity a priest is called for the people in deathbed. They confess their sins and receive the priest's blessing ${ }^{\prime 35,6}$. Burian's approach, like the majority of the translations discussed in this study, is an example of "gloss translation," which, in Nida's terms is "designed to permit the reader to identify himself as fully as possible with a person in the source-language context, and to understand as much as he can of the customs, manner of thought, and mean of expression" (2000, p. 129). Aiming at "formal" equivalence, "such a translation would require numerous footnotes in order to make the text fully comprehensible" (Ibid.).

\section{Sabahattin Eyüboğlu's Hamlet}

The next Hamlet in Turkish appears in $1965^{7}$ and is translated by the author, academician Sabahattin Eyüboğlu. This translation is still widely used by theatre companies (and often used as a sub/surtitle on stage and movie theatres). However, its popularity makes the translator's afterword immensely salient: Being a professor of French, Eyüboğlu admits the fact that he had learned English on his own, and hence, during the translation process made use of earlier Turkish and French translations of the play. Eyüboğlu relates this process as follows: "By the help of these translations, I was trying to comprehend the original text and then, was trying to find equivalence in my own way. Thereby, I realized that each translator had reshaped Shakespeare. Who knows how I reshaped him unavoidably [...] Each translator took Hamlet to his/her own world"8 (Shakespeare, 1995, p. 177).

5 My translation.

6 In 1992 Can Yücel translates this section with not only a reference to the Catholic act of confession but also to "kelime-i şahadet," which is the Islamic confession of faith. His approach (which will be discussed in the following pages) makes the Turkish reader/audience comprehend the circumstances with utterly localized references.

7 The version that is used in this essay is the 6th edition of the translation that was published by Remzi Kitabevi in 1995. It is worth mentioning that since 1999 the publishing house Remzi Kitabevi is publishing Bülent Bozkurt's translation, which will be discussed in the following pages. Eyüboğlu's version, however, is now published by another publishing house, Türkiye Iş̧ Bankası Yayınları.

My translation. 
One of the first things that attract the reader/audience's attention is that the use of verse and prose is utterly in accordance with the source text. Moreover, "the distinguishing characteristic of this version is seen to lie in its free-flowing poetic prose, akin to free verse, which follows the lineation of the original, the diction being the same as that of contemporary Turkish poetry rooted in a simple and natural use of the language" (Paker, 1986, p. 100). Since the choices of the translator are reflective of his/her background and worldview, understanding of the source as well as the target culture and the current changes in the target language, the major differences between Eyüboğlu's translation and its predecessors are significant in displaying the distinction between the Turkish culture and language in the 1940s and the 1960s. The most apparent of these differences seems to be the ongoing simplification of Turkish language. Emphasizing the significance and supremacy of the common people in most of his essays and literary works, Eyüboğlu's focus on "people's language" can be traced in his Hamlet translation as well.

Furthermore, while translating the source text, Eyüboğlu localizes certain aspects of the play. Defining Ophelia and the Gravedigger's songs as türkü [Turkish folk song] instead of şarkı [song], he is apparently accentuating the essence of these songs. Similar to the fact that Shakespeare's contemporaries were most probably accustomed to those particular songs or the themes that are prominent within these fragments of songs, the Turkish reader/audience is familiar with "türkü" as a special form of song. The unavoidable relation between the term türkü and the word Türk (Turk/Turkish) indicates that this specific type of song is exclusive to Turkish culture. The word türkü is the equivalent of the folk song in Turkish culture, and by its nature, the folk song is distinctive in relation to the culture or folk producing it:

Given the highly redundant nature of folk song and the fact that song is usually a group communication device serving to focus the attention of groups, to organize them for joint response, and to produce consensus, it seems obvious that the texts of songs will be limited to those matters, attitudes, concerns, and feelings on which the community is in maximal accord. (Lomax \& Halifax, 2000, p. 275)

In this respect, the term folk song as well as its contents have certain implications for a given group or culture. Although the term türkü creates a shift of meaning by introducing a Turkish element into the Danish court, the themes of the songs sung by Ophelia and the Gravedigger are universal, causing the same kind of reaction in many 
cultures. Despite the similarity between the English folk song and türkü with respect to their nature, the term türk $\ddot{u}^{9}$ stands contradictory to the Danish characters' (created by an English playwright) identity ${ }^{10}$.

Eyüboğlu presents a similar shift of expression and localization while defining the players visiting Elsinore, too. He translates "the tragedians of the city" (II.2.327) as "şehir tiyatrosu oyuncuları" which literary means [the players of the city theatre]. The significance of this particular translation lies in the fact that şehir tiyatrosu is the exact term used for the institutional city theatres around Turkey. Like the term türkü, şehir tiyatrosu oyucuları has an entirely specific meaning and significance in the eyes of the Turkish reader/audience. Founded during the Ottoman era (1914) with the name Dârülbedayi-i Osmani [the Ottoman House of Beauty], the modern şehir tiyatrosu is an official institution, which is totally dependent on local governments in terms of allowance. With respect to this translation, it is inevitable that the modern Turkish audience's perception of the players arriving in Elsinore is utterly different from that of the Elizabethan audience's because the Elizabethan theatre groups and the modern Turkish city theatres represent different aspects of theatre. The major difference between these two lies in their establishment: even though almost all of the Elizabethan theatre companies were under the patronage of aristocrats in order to survive, and they were performing under unofficial external control, the actors working at şehir tiyatroları (who have to be graduates of drama school) are expected to follow the written rules and regulations determined by the local governments. Although the players of şehir tiyatroları occasionally perform on tours around Turkey, it is known that Elizabethan theatre companies mostly travelled. In this respect, the Elizabethan travelling groups - including the actors visiting Elsinore in Hamlet - display the continuence of a Medieval tradition. Hence, the terms used for the actors in the source text and Eyüboğlu's translation illustrate different traditions and establishments.

9 We must also point out the fact that the discussion related to the translation of the words "song" and "singing" continues in Bozkurt's version as well. Although he translates the stage directions as "şarkı söyler" meaning "she sings [a song]", he lets Ophelia say: "şöyle söyleyeceksin türküyü" [this is how you are going to sing the Turkish folk song].

10 Contrary to his introduction of the term türkü, Eyüboğlu's response to the only reference to Turks in the play is worth mentioning. Hamlet, while talking to Horatio in 3.2 says "Would not this, sir, and a forest of feathers, if the rest of my fortunes turn Turk with me, with Provincial roses on my razed shoes, get me a fellowship in a cry of players?" (3.2.269-271). Harold Jenkins explains the phrase "turn Turk with me" in the footnote as to "become an infidel; hence play false, be treacherous." Halide Edib and Vahit Turhan, Orhan Burian, Sabahattin Eyüboğlu and Özdemir Nutku translate this phrase without making any reference to the word "Turk," simply focusing on the meaning of the idiom. Bülent Bozkurt, however, translates the idiom by using the word "Turk" and then explains the function of the word "Turk" within this idiom. Can Yücel, who presents no footnote in his version of the play, translates the idiom using the word "Turk" and does not present any kind of explanation. 


\section{Bülent Bozkurt's Hamlet}

In 1982 Bülent Bozkurt (also a professor of English) translates Hamlet with a comprehensive introduction including the following sub-sections: (i) the life of Shakespeare, (ii) a brief discussion on the sources and the significance of the play, (iii) notes on the translation process, (iv) stage production history of the play, (v) list of the characters, and (vi) the pronunciation of the names of the characters. Although the first five sections are mostly common in other translations, the last section focusing on how to pronounce the names of each and every character (including those who are only referred to such as Yorick), is significant in evidently implying that this translation does not only address the reader but also the actors. Nonetheless, Bozkurt's academic approach is apparent throughout the text: Exemplifying Nida's formal equivalence/gloss translation, there are eighty-two footnotes throughout this translation. Similar to its predecessors, it reveals Bozkurt's role as an academician explaining mythological characters such as Hyperion, as well as his eagerness to comment upon certain phrases and sentences.

The ongoing process of translating Hamlet into Turkish is exemplified through Bozkurt's translation since he edited his own translation in 1999. When the difference between the languages employed in Halide Edib Adıvar and Sabahattin Eyüboğlu's versions is taken into consideration, the journey Turkish language has been going through since the 1920s can be observed with utmost clarity. Bozkurt however, employs a flexible midway by making it possible for the old idioms and words to co-exist with those accentuated while purifying Turkish language. Pointing out the tension between the old Turkish, which is under the influence of the Ottoman language and the purification process, Bozkurt argues that "the victims of the transition period are comfortable neither with sözcük nor kelime"11 (2013a, p. 21). Suggesting that he does not feel obliged to use old words and phrases while translating a text dating back to the sixteenth century, Bozkurt is understood to have chosen both Ottoman and purified words, depending on contextual equivalence, fluency and sound ${ }^{12}$.

Another significant aspect of Shakespeare translations is the form: whether to imitate Shakespeare's way and compose the text in verse or to rewrite the play in prose basing

11 My translation.

12 The question whether to use kelime (derived from the Arabic kalïma) or sözcük (derived from the Turkish söz) for "word" in Turkish has often been regarded as one of the indicators of the difference between the old and purified languages. 
the decision on the syntaxical, rhytmical differences between Turkish and English as Turhan does in his aforementioned essay. Commenting upon his personal choice, Bozkurt argues that "presenting the lines in verse does not suggest a claim of lyricism which is comparable to Shakespeare. The aim is to make it understood that Shakespeare does not write prose but poetry; to preserve the meaning and idioms in the text; to help some "artificiality" to be apparent and to make the reading process easier"13 (Ibid.). Without disregarding the differences between Turkish and English, Bozkurt makes a visible correlation between the source text and the target text not only by presenting the play in verse but also by presenting line numbers within the text. Nonetheless, one needs to be cautious about the fact that due to the syntactic differences between the source and target language, the line numbers in the target text do not necessarily coincide with those in the source text.

\section{Can Yücel's Hamlet}

Possibly the most controversial Hamlet translation is made by Can Yücel (1992), a Turkish poet and translator, who is known for his use of slang and colloquial language in his works. Being the son of the first Minister of Education, Hasan Ali Yücel (who was the Minister when Orhan Burian's Hamlet translation was commissioned and published), Can Yücel studied classical philology in Ankara and Cambridge University. His translations are considered to be exemplifying what Nida calls "dynamic equivalence": "A translation of dynamic equivalence aims at complete naturalness of expression, and tries to relate the receptor to modes of behaviour relevant within the context of his own culture; it does not insist that he understand the cultural patterns of the source-language context in order to comprehend the message" (2000, p. 129). Yücel's translations are so "dynamic" that, he defines himself as Türkçe söyleyen [the person who tells in Turkish] rather than a translator emphasising translation's relation to adaptation. His perception of translation is in accordance with André Lefevere's theory which identifies translation as a form of rewriting and hence, refuses to consider the translation to be secondary. While explaining his purpose of translation, Yücel suggests that he tends to imagine what the author of the source text would have done if he/she were Turkish. This viewpoint, unquestionably, makes the act of translation target text/culture/language oriented.

In Yücel's translation, transcultural relationship becomes extremely vivid with numerous references to Turkish culture. One of the most striking examples of this

13 My translation. 
transcultural relationship is the translation of "to be or not to be." Instead of focusing on the syntax or Hamlet's choice of words, Yücel translates this sentence with reference to an old Turkish song, "Bir ihtimal daha var." Composed by Osman Nihat Akın (19051959), the song is considered to be a fine example of Classical Turkish Music. The first two lines of the song that are used by Yücel as the Turkish equivalent to "to be or not to be that is the question" are "Bir ihtimal daha var / O da ölmek mi dersin," which can be translated as "There is one more possibility / and that, you would say, is to die?" Although the first lines of the song seem to be in accordance with the soliloquy's beginning (simply by making a reference to the question of death), the totality of the lyrics is a declaration of love, asking the beloved not to remain silent for he/she is worth a lifetime. Yücel's approach to Hamlet's renowned soliloquy obviously results in a shift of meaning as far as Shakespeare's main argument in those lines are concerned. However, by making the Prince of Denmark refer to a well-known Turkish song, Yücel allows the Turkish reader feel that Hamlet is one of "them."

Another significant example of localization in Yücel's version of Hamlet is in accordance with one of the topics discussed in relation to Eyüboğlu's translation. "The tragedians of the city" (2.2.327) are now Kenterler in Yücel's 'rewriting'. Kenterler [the Kenters] or Kenter Tiyatrosu [Kenter Theatre] is one of the leading private theatre companies in Turkey since the 1960s. Founded by a brother and a sister - Müşfik Kenter and Yıldız Kenter- the company's repertoire includes both Turkish and foreign playwrights from Shakespeare to Martin McDonagh, from Jean Anouilh to Chekhov. Needless to say that, Hamlet has always been one of the highlights of this repertoire since 1969. When Hamlet and Rosencrantz's dialogue on the current changes in the theatrical world is taken into consideration, Yücel's reference to Kenter Tiyatrosu becomes significant in symbolizing the norm and tradition against the emergence of alternative approaches to theatre. Yücel's deliberate choice of translating "the tragedians of the city" as Kenterler can be argued to be a reference to the fact that it has always been regarded as one to the most respectable ecoles of Turkish theatre.

\section{Özdemir Nutku's Hamlet}

The next Hamlet translation following Yücel's utterly localized version appears in 2013 and is translated by Özdemir Nutku, who is a professor of theatre studies and a director. Working professionally on both theoretical and practical levels of theatre, Nutku not only points out the dynamics of the text but also examines it as a scenario 
in his introduction. Accordingly, he emphasizes the fact that "this play was written for theatre" ${ }^{\prime 14}$ (Shakespeare, 2013b, p. 17). Stating that he uses the Ginn \& Company version of the source play edited by George Lyman Kittredge, Nutku bases his argument on Jan Kott, who suggests that "Hamlet is like a sponge [...] This scenario is independent from the characters; it has been devised earlier. It defines the situations, as well as the mutual relations of the characters; it dictates their words and gestures. But it does not say who the characters are" (1967, p. 52).

In his fourteen-page introduction, Nutku presents the reader the history of the play and Shakespeare's perception of theatre through an analysis of the dialogues between Hamlet and the players of the city. Next, he demonstrates the amount and nature of corruption in the Danish court as presented within the source text. Furthermore, there are ninety-three endnotes explaining or commenting upon certain dialogues analysing the relationship between characters, the setting, word plays (Nutku even presents the English words or phrases and then comments upon the translation process mentioning the alternatives which were left behind), mythological characters, and the characteristics of the era (both the Danish court and Elizabethan England). Nutku often refers to Kittredge in these endnotes, and evidently reflects the view of this particular edition used as the source text. When Nutku's general approach to the text is taken into consideration, it is observed that he emphasises acting as a bridge between the sixteenth century English text and the twenty first century Turkish reader/audience without portraying Hamlet as a problematic character whose language is torn in between cultures. While employing modern Turkish, he presents his translation without localising the play as much as his predecessors in the last decades.

\section{Conclusion}

Analysing Hamlet translations in Turkish, displays the changes in the Turkish language and culture since 1908 as well as the significance of Shakespeare in the Turkish cultural scene. Since translating a literary work can be described as an attempt to make the text and the source culture familiar to the target culture and reader, Shakespeare's works become a solid part of the bridge between the English and Turkish cultures. Although it is a global tendency to translate major literary works repeatedly to be published by different publishing houses, each translation that is discussed in this study reflects different scopes, which are mostly related to the transformation process

14 My translation. 
Turkey and the Turkish language have been going through. The changes in daily life, language, cultural structure, and relation to other countries play a significant role in the translator and the publishing house's translation policies. This study suggests that the purification or simplification procedure in the Turkish language is one of the key contrasts between the earliest and the later translations of Hamlet. Apart from the nature of the language employed in these translations, the most apparent cause of shifts of expression is the translator's inclination to add local elements to the text. Despite the fact that all translations that are analysed in this study slightly differ from one another in terms of scope, language, and target reader/audience, they doubtlessly establish a dialogue between the characters in Hamlet and the Turkish reader/audience.

Peer-review: Externally peer-reviewed.

Conflict of Interest: The author has no conflict of interest to declare.

Grant Support: The author declared that this study has received no financial support.

Hakem Değerlendirmesi: Dış bağımsız.

Çıkar Çatışması: Yazar çıkar çatışması bildirmemiştir.

Finansal Destek: Yazar bu çalışma için finansal destek almadığını beyan etmiştir.

\section{References}

Ayluçtarhan, S. (2007). Dr. Abdullah Cevdet's Translations (1908-1910): The Making of a Westernist and Materialist 'Culture Repertoire' in a 'Resistant' Ottoman Context, MA Thesis. Boğaziçi University, Istanbul.

Bozkurt, B. (2013). Hamlet'i Türkçe'ye Çevirirken, W. Shakespeare, Hamlet (pp. 17-21) (B. Bozkurt, Trans.). Istanbul: Remzi Kitabevi.

Das Gupta, J. (1968). Language Diversity and National Development, J. A. Fishman, C. A. Ferguson, J. Das Gupta (Eds.). Language Problems of Developing Nations (pp. 17-28). New York \& London: John Wiley \& Sons, Inc. Enginün, İ. (1979). Türk Edebiyatında Shakespeare: Tanzimat devrinde tercüme ve tesiri. Istanbul: Dergah Yayınları. Even-Zohar, I. (1990). The Position of Translated Literature within the Literary Polysystem, Poetics Today 11 (1),

Durham, NC: Duke University Press, 45-51.

Kott, J. (1967). Shakespeare our Contemporary (B. Taborski, Trans.). London: Methuen \& Co Ltd.

Lomax, A. \& Halifax, J. (2000). Folk Song Texts as Culture Indicators. A. Lomax (Ed.). Folk Song and Culture (pp. 274-299). New Brunswick \& London: Transaction Publishers.

Nida, E. (2000). Principles of Correspondence, L. Venuti (Ed.). The Translation Studies Reader (pp. 126-141). London: Routledge.

Paker, S. (1986). "'Hamlet' in Turkey", New Comparison: A Journal of Comperative and General Literary Studies, 2 (Autumn), Norwich: University of East Anglia, 89-105. 
Paker, S. (1991). "Turkey", R. Ostle (Ed.). Modern Literature in the Near and Middle East 1850-1970 (pp. 17-32). New York: Routledge.

Shakespeare, W. (1941). Hamlet: Danimarka Prensi (H. Edib \& V. Turhan, Trans.). Istanbul: Istanbul Cumhuriyet Matbaası. (1603)

Shakespeare, W. (1946). Hamlet (O. Burian, Trans.). Istanbul: Milli Eğitim Basımevi. (1603)

Shakespeare, W. (1992). Hamlet (C. Yücel, Trans.). Istanbul: Adam Yayınları (1603)

Shakespeare, W. (1995). Hamlet (S. Eyüboğlu, Trans.). Istanbul: Remzi Kitabevi. (1603)

Shakespeare, W. (1997). Hamlet (H. Jenkins, Ed.). Surrey: Thomas Nelson \& Sons (1603)

Shakespeare, W. (2013a). Hamlet (B. Bozkurt, Trans.). Istanbul: Remzi Kitabevi. (1603)

Shakespeare, W. (2013b). Hamlet (Ö. Nutku, Trans.). Istanbul: Mitos Boyut. (1603)

Turhan, V. (1965). "Shakespeare in Turkish", Litera Vol.8, Istanbul: Istanbul University Press, 49-61. 